gas-turbine exhausting direct to the atmosphere, and an electric generator. "The present-day possibilities of realising a successful gas-turbine, resulting from the improvement of the compressor efficiency on the one hand, and the availability of heat resisting materials on the other hand, would have appeared unthinkable but a short time ago."

When the set is working, with the temperature of the atmosphere about $77^{\circ} \mathrm{F}$, air from the compressor is discharged at a pressure of about $60 \mathrm{lb}$. per sq. in. and a temperature of nearly $400^{\circ} \mathrm{F}$. to the combustion chamber. The fuel is gas oil. Only a part of the air is used for combustion, the remainder being used to bring down the temperature of the burnt gases to about $1,000^{\circ} \mathrm{F}$., at which temperature they enter the turbine. After doing work in the turbine, the gas is exhausted to the atmosphere at a temperature of about $500^{\circ} \mathrm{F}$. The set is rated at 4,000 kw., and revolves at 3,000 r.p.m., producing three-phase current at 50 cycles. The thermal efficiency is $17 \cdot 38$ per cent. The gas turbine, says Prof. Stodola, has many promising possibilities which merit the attention of prime-mover designers and of leaders of industry.

\section{Swiss Watch-making Industry}

IN Swiss Technics, published by the Swiss Office for the Development of Trade, in Zurich and Lausanne, during November-December 1939, it is stated that although less trade was carried out during the first few months of the year than during the corresponding months of 1938 there was decided improvement in the summer, so that exports to most foreign countries very nearly reached the 1938 figures. This progress would certainly have been maintained had it not been for the War. It would be absurd to give way to despondency with regard to the future of the Swiss watch-making trade. There are two good reasons for looking forward hopefully. The first is the great improvements made by the industry in perfecting watches during the last ten years. The improvements have been continuous.

The 1939 steel watch is proof against fall, shock and damp. It is antimagnetic and does not oxidize. It unites a number of advantages and improvements not found in the best watches made before the War of 1914-18. The manufacturers are not afraid of losing their customers. As an example they give Great Britain, where the demand is increasing owing to the greater need for punctuality. The second reason lies in the organization of the Swiss watch-making industry. The watches are made of good materials and with great technical skill. Quite poor people will always find good watches at a price suited to their purses. Competition which the Swiss might justly have feared has now disappeared. They are therefore prepared to provide the world with the three types of watches produced by a trade that is built up on sound principles: chronometers and precision instruments, suitable for observatories, beautiful high grade watches, and cheaper watches which nevertheless keep good time. It is thus that the Swiss industry faces the great crisis.

\section{Earth Tremors in Belgium}

ON January 7 two earthquake tremors were distinctly felt in the district immediately to the east of Mons, one at about 4.30 p.m. and the other at about 8.30 p.m. These were recorded at the Uccle Observatory at 4.29 p.m. and 8.32 p.m. respectively and the epicentre appears to have been near latitude $50^{\circ} 26^{\prime} \mathrm{N}$., longitude $4^{\circ} 0^{\prime} \mathrm{E}$. No damage or casualties are reported. It will be remembered that a much stronger earthquake did damage to property and caused injury to ten people in Belgium on June 11, 1938 (Nature, 144,950 ; 1939). On that occasion the epicentre was determined by the chief of the Belgian Seismological Service, Dr. O. Somville, to have been between Audenarde and Renaix, latitude $50^{\circ} 47^{\prime}$ N., longitude $3^{\circ} 35^{\prime} \mathrm{E}$. The 1940 epicentre thus appears to have been a little to the south and east of the 1938 epicentre, though any connexion between them is doubtful. The 1938 earthquake had a depth of focus of $45 \mathrm{~km}$. though the 1940 one may have been superficial.

\section{Development of Moscow}

A BOOKLET recently issued in Moscow entitled "Moscow in Figures" (London: Russia To-day Press Service) shows the development of the Soviet capital in recent years. According to the figures given, during the last thirteen years the population of Moscow has more than doubled, at present numbering 4,137,000. Moscow is now the third largest city in the world. The number of workers and employees in the factories and institutions of Moscow in 1939 reached 2,300,000, as against 600,000 in 1913 . In 1938 there were 117,200 births in Moscow. The city has 175 scientific research institutions in which 9,000 scientific workers are engaged. The higher educational institutions of Moscow have, 95,000 students. During the last four years 350 new schools have been built. The number of pupils at present attending the Moscow schools is 608,300 .

\section{Hygiene in South China}

THE November issue of the Bulletin de l'Office d'Hygiène Publique contains an account by InspectorGeneral Dr. A. Lasnet, the delegate of Algeria, of a sanitary mission sent by the Health Section of the Jeague of Nations to South China in December 1937, six months after the onset of the war between China and Japan. The work of the mission consisted in (1) a campaign against infectious diseases, especially smallpox during the cold season, cholera during the hot season and malaria in the spring and summer; (2) wholesale destruction of insanitary houses, construction of wide sunny streets, proper disposal of excreta, and protection of the water supply; (3) education of the population in hygiene.

\section{Detection of Toxic Gases}

Leaflets 8 and 9 of "Methods for the Detection of Toxic Gases in Industry", published by the Department of Scientific and Industrial Research 